ARTICLE

DOI: $10.1038 /$ ncomms13241

OPEN

\title{
Robust homology-directed repair within mouse mammary tissue is not specifically affected by Brca2 mutation
}

Elizabeth M. Kass ${ }^{1}$, Pei Xin Lim¹, Hildur R. Helgadottir ${ }^{1}$, Mary Ellen Moynahan ${ }^{2} \&$ Maria Jasin ${ }^{1}$

The mammary gland undergoes significant proliferative stages after birth, but little is known about how the developmental changes impact DNA double-strand break (DSB) repair. Mutations in multiple genes involved in homology-directed repair (HDR), considered a particularly accurate pathway for repairing DSBs, are linked to breast cancer susceptibility, including BRCA2. Using reporter mice that express an inducible endonuclease, we find that HDR is particularly robust in mammary tissue during puberty and pregnancy, accounting for $34-40 \%$ of detected repair events, more than in other tissues examined. Brca2 hypomorphic mutation leads to HDR defects in mammary epithelium during puberty and pregnancy, including in different epithelial lineages. Notably, a similar dependence on Brca2 is observed in other proliferative tissues, including small intestine epithelium. Our results suggest that the greater reliance on HDR in the proliferating mammary gland, rather than a specific dependence on BRCA2, may increase its susceptibility to tumorigenesis incurred by BRCA2 mutation.

\footnotetext{
${ }^{1}$ Developmental Biology Program, Memorial Sloan Kettering Cancer Center, 1275 York Avenue, New York, New York 10065, USA. 2 Department of Medicine, Memorial Sloan Kettering Cancer Center, 1275 York Avenue, New York, New York 10065, USA. Correspondence and requests for materials should be addressed to M.J. (email: m-jasin@ski.mskcc.org).
} 
D NA double-strand breaks (DSBs) in mammalian cells are repaired by two major pathways, homology-directed repair (HDR), and non-homologous end joining (NHEJ) ${ }^{1}$. HDR is considered the more precise of the pathways because it usually involves repair from the identical sister chromatid ${ }^{2}$, whereas NHEJ can be prone to errors. NHEJ is often thought to be the predominant pathway for repair ${ }^{3,4}$, especially in the animal where most somatic cells are not cycling. However, quantitative in vivo measurements in tissues to accurately assess the contribution of each pathway to DSB repair have been lacking.

In their capacity as genomic caretakers, many HDR genes are breast tumour suppressors ${ }^{5,6}$, including $B R C A 1$ and $B R C A 2$, suggesting the importance of this DNA repair pathway for tissues or tissue compartments that proliferate postnatally and may thus be particularly at oncogenic risk when breaches occur to this pathway. The mammary gland undergoes significant postnatal development during puberty and pregnancy ${ }^{7}$. These stages have been implicated in the epidemiology of breast cancer risk $^{8,9}$, but how they may impact DSB repair is unknown.

Reporters containing repeat sequences have been used to detect homologous recombination events in both somatic and germ line cells of the mouse for almost two decades, but typically these events are rare $^{10-15}$. Furthermore, when assaying spontaneous events, variation between animals can be high, requiring the use of large numbers of mice for mutant comparisons ${ }^{14}$. Thus, novel systems need to be developed to interrogate HDR within animal tissues.

Here we develop such a system where a defined lesion-a DSB - is efficiently introduced into the genome, allowing us to examine HDR within proliferative tissues. In this system, we couple mice containing the widely used reporter for HDR, direct repeat-green fluorescent protein (DR-GFP) ${ }^{16}$, with those developed to contain doxycycline-inducible I-SceI endonuclease for DSB formation. Because I-SceI endonuclease has a long recognition site $(\sim 18 \mathrm{bp})$, its expression is not toxic to cells ${ }^{17}$. We show that HDR of the I-SceI-induced DSB is robust in mammary epithelium during the proliferative stages of puberty and pregnancy, comprising one-third or more of total DSB repair events, and is also frequent in the small intestine epithelium. Mutation of Brca2 reduces HDR to a similar extent in mammary epithelium and other tissues. Further, mutation of Brca2 impacts HDR similarly in different mammary epithelial cell lineages, consistent with the heterogeneous nature of BRCA2-deficient breast tumours ${ }^{18}$.

\section{Results}

High HDR in mammary tissue during puberty and pregnancy. We previously generated mice containing the HDR reporter DR-GFP integrated into their genome on chromosome 17 (ref. 15) (Fig. 1a). The DR-GFP reporter consists of two defective GFP genes; a DSB introduced into the upstream gene by the I-SceI endonuclease and repaired by HDR with the downstream gene gives rise to GFP + cells. By contrast, repair by imprecise NHEJ disrupts the DSB site without restoring a functional GFP gene. To study HDR within tissues in the animal, DR-GFP reporter mice were generated that express I-SceI under the control of a doxycycline (Dox)-inducible promoter (Fig. 1a and Supplementary Fig. 1a-d) and driven by CMV-rtTA (ref. 19).

Given the association between HDR gene mutation and mammary tumour predisposition, we first tested this I-SceI DR-GFP system in mammary cells. Epithelial cells were isolated from the fourth inguinal mammary glands from 2-3-month-old virgin mice and Dox was added to the culture for 2 days. Tightly controlled expression of the HA-tagged I-SceI endonuclease was observed in these primary cultures and, concordantly, a large induction in the number of GFP + cells was detected by flow cytometry ( $8 \%$; Fig. 1b). The HDR induction is $\sim 10$-fold higher than what we previously observed in primary mammary epithelial cells that were transiently transfected with an I-SceI expression vector $^{15}$, demonstrating the advantage of the inducible system for analysing HDR.

To induce I-SceI within the proliferative mammary epithelium of the animal, pubertal (33-35 days old) and pregnant (5.5-8.5 days post coitum) mice were given Dox in their drinking water for 9 days and the mammary glands were then harvested. Tissue sections stained with an anti-HA antibody demonstrated Dox-dependent expression of I-SceI in both the pubertal and pregnant gland (Fig. 1c). Similarly treated adult virgin mice (2-3 month old) showed many fewer cells expressing I-SceI and so were not further analysed (Supplementary Fig. 1e).

To examine HDR, sections from pubertal mice were stained for GFP as well as cytokeratin 14 (CK14), which is present in the basal cells that make up the outer layer of the duct (Fig. 1d). With I-SceI expression, GFP + cells were frequent and dispersed throughout the gland in both the luminal and basal layers, demonstrating the non-clonal origin of the cells. By flow cytometry, $\sim 6 \%$ of mammary epithelial cells in the pubertal tissue were GFP + (Fig. 1e). A similar analysis was performed in mammary tissue during pregnancy, except that cytokeratin 8 (CK8) was used to identify cells lining the lumen (Fig. 1d). As with the pubertal mice, the pregnant mice demonstrated a large number of GFP + cells dispersed throughout the gland, such that $\sim 10 \%$ of the mammary epithelial cells in the tissue were GFP + (Fig. 1e). In the absence of Dox, the level of GFP + cells was substantially lower (pubertal, $0.05 \%$; pregnant, $0.23 \%$; Supplementary Data 1). Thus, with this system HDR can be induced and readily detected within a tissue in the animal.

We next asked whether HDR was enriched in replicating cells. Dox-treated mice were pulsed with EdU for $24 \mathrm{~h}$ before mammary gland harvest. Whereas $\sim 11 \%$ of cells in the total epithelial population was GFP,$+ \sim 34 \%$ of the EdU-positive cells were GFP + (Fig. 1f and Supplementary Fig. 1f). These results are consistent with HDR occurring within the S and G2 phases of cycling cells.

NHEJ is often considered the predominant DSB repair pathway in mammalian cells ${ }^{3,4}$. To determine the relative contribution of HDR, a PCR-based I-SceI site loss assay was utilized to measure total DSB repair from imprecise NHEJ and $\mathrm{HDR}^{20}$ (Fig. 1g). Genomic DNA was collected from cells at the time of GFP analysis for PCR with primers that flanked the break site. The resultant amplification product was cleaved by I-SceI in vitro and the fraction of uncleaved DNA ('site loss', red arrow) arising from DSB repair was determined. Site loss was 16 and $30 \%$ in the mouse pubertal and pregnant epithelium, respectively (Fig. 1h), indicating efficient DSB induction and repair. Overall, HDR, as determined by the per cent GFP + cells relative to site loss for each sample, was observed to be high, such that $40 \%$ and $34 \%$ of the DSB repair events in the pubertal and pregnant glands were from HDR, respectively (Fig. $1 \mathrm{~h}$ and Table 1). Thus, in the proliferating mammary gland, HDR is a robust DSB repair pathway.

HDR varies within different mammary epithelial cell subtypes. Mammary epithelium is composed of cells from different lineages including luminal cells that line the duct and the surrounding contractile basal (myoepithelial) cells ${ }^{21}$. Understanding DNA repair in the specific cell populations in the mammary epithelial cell hierarchy is critical to understanding potential effects of cancer-predisposing genetic mutations in the mammary gland, as different lineages may contribute to 
a
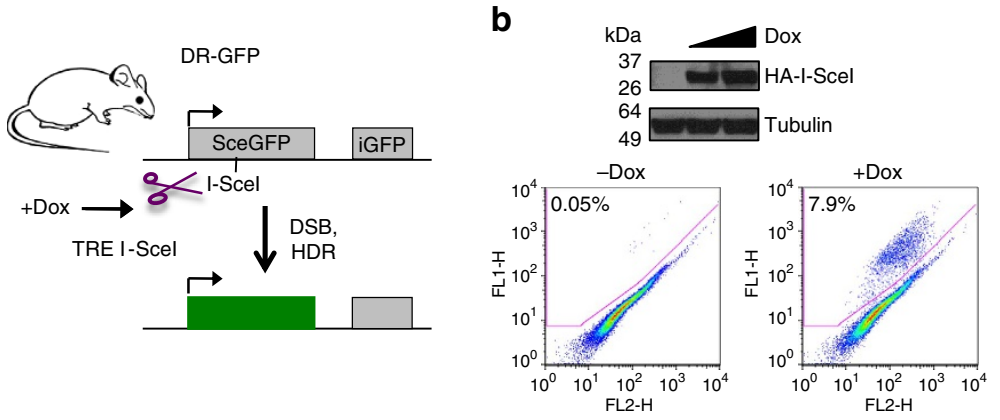

d
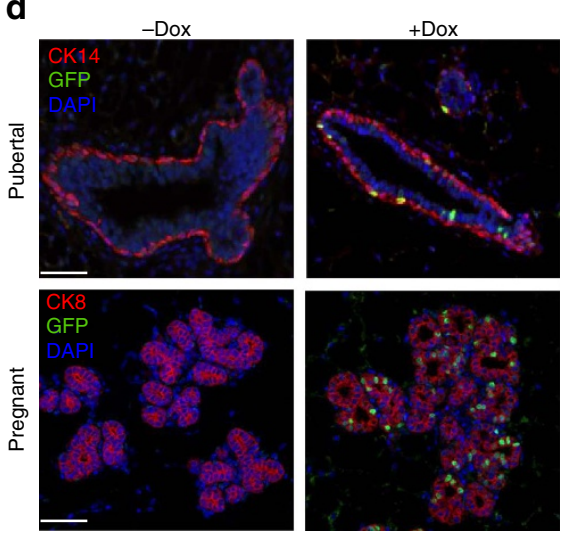

e

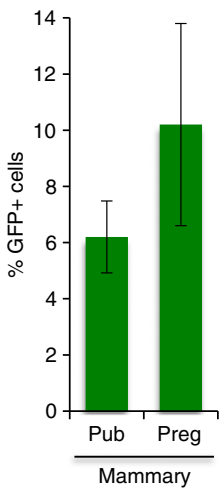

f

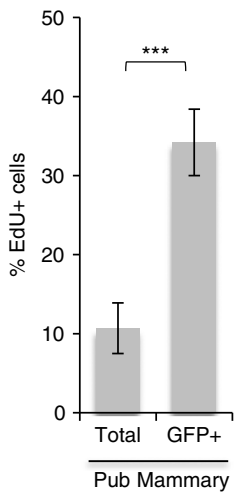

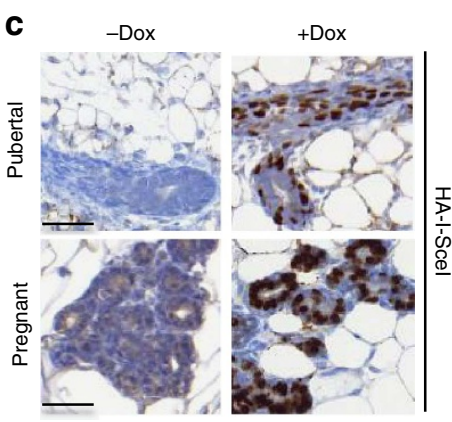

g

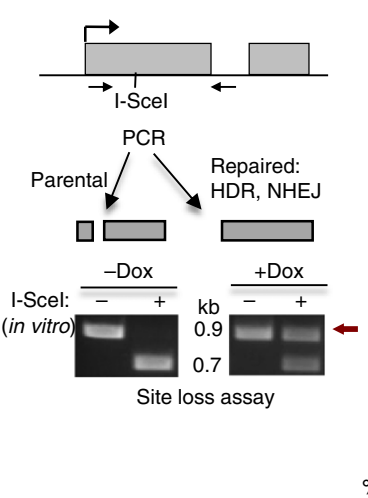

h

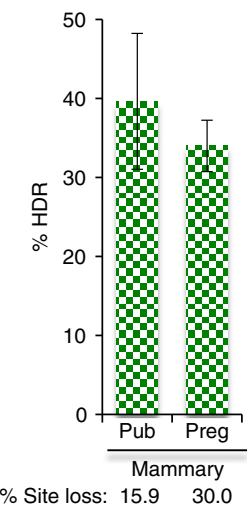

Figure 1 | HDR is high in mammary tissue during proliferative stages of development. (a) I-Scel DR-GFP mouse model. Dox treatment of mice leads to I-Scel expression. HDR of the I-Scel-induced DSB in SceGFP using iGFP as template results in GFP expression. (b) Primary mammary epithelial cells show high levels of HDR upon Dox addition to the culture. Cells were isolated from an 8-week-old virgin female I-Scel DR-GFP mouse; Dox was added to induce I-Scel expression and $48 \mathrm{~h}$ later cells were collected for flow cytometry and western blot analysis. The mean \%GFP + cells is shown. (c) I-Scel expression is detected in mammary tissue from pubertal and pregnant mice using an anti-HA antibody. Scale bars, $50 \mu m$. (d) HDR is detected by immunofluorescence in mammary tissue from pubertal and pregnant mice using anti-GFP and cytokeratin antibodies (pubertal, CK14; pregnant, CK8). Nuclei are visualized by DAPI. GFP is localized to the nucleus. Scale bars, $50 \mu \mathrm{m}$. (e) The \%GFP + cells, measuring HDR events, is high in mammary tissue during puberty and pregnancy. Mammary epithelial cells were dissociated from freshly harvested tissue from 6-week-old pubertal mice $(n=6)$ and $14.5-17.5$ dpc pregnant mice $(n=9)$ treated with Dox for 9 days before harvest. Error bars here and in subsequent figures represent s.d. (f) The GFP + population is enriched for $\mathrm{EdU}+$ cells. Glands were harvested from 5 -week-old wild-type mice $(n=4)$ treated with Dox for 3 days; $24 \mathrm{~h}$ before harvest, mice were given a single intraperitoneal injection of EdU at $0.5 \mathrm{mg}$ per10 g mouse weight. ${ }^{\star \star \star} P=0.0001$ (student's t-test; two-tailed). (g) Site loss assay to measure DSB repair from imprecise NHEJ and HDR combined. The PCR product is cleaved in vitro if a DSB was not induced or was precisely repaired in vivo, but not cleaved (red arrow) in vitro if repair by HDR or NHEJ in vivo leads to I-Scel site loss. (h) HDR is high in mammary tissue during puberty and pregnancy. The \%HDR is the $\%$ GFP + cells determined by flow cytometry divided by $\%$ site loss. The $\%$ site loss for mice in $\mathbf{e}$ is shown below.

tumours with specific genetic backgrounds. To examine HDR within different lineages in the mammary gland, epithelial cells dissociated from freshly harvested tissue from Dox-treated mice were co-stained with antibodies to the cell surface markers CD24 and CD49f (ref. 22) (Fig. 2a). In pubertal mice, $\mathrm{GFP}+$ cells were robustly detected in both populations, with the per cent HDR higher in the luminal population, approaching $50 \%$ when site loss was taken into account (1.4-fold; Fig. 2b). Similarly, the luminal population during mid-pregnancy was enriched in GFP + cells and was also confirmed to have a higher level of HDR than the basal population (1.5-fold; Fig. 2c and Table 1).

Mammary stem cells with the hallmark features of multi-lineage differentiation and self-renewal drive growth associated with ductal elongation during puberty in the terminal end buds and are believed to fractionate in the $5 \%$ of basal cells that express the highest levels of CD24 and CD49f (refs 23,24) (Fig. 2a and Supplementary Fig. 1g). Notably, we found that the highest percentage of GFP + cells in the mammary gland was in this stem cell fraction, $\sim 2.2$-fold over the non-stem cell basal population (Fig. 2b). While it is generally thought that most adult stem cells are slow dividing and exist in a quiescent state, activated stem cells have been proposed to drive proliferative changes during puberty ${ }^{7,25}$. Although stem cells represent a small fraction of the basal compartment, a precise repair pathway would be particularly important for these repopulating cells to faithfully transmit genetic information.

Reduced HDR in mammary tissue from Brca2 mutant mice. The breast cancer suppressor BRCA2 has been established to play a critical role in HDR in embryonic cells and transformed cell lines ${ }^{26}$. To determine whether Brca2 mutation differentially affects HDR in mammary epithelium compared with other tissues, we used a hypomorphic allele of Brca2, which unlike null alleles of Brca2, permits survival of the mice through embryogenesis. The $B r c a 2^{427}$ allele encodes a peptide that retains binding to several $\mathrm{HDR}$ proteins, but lacks the $\mathrm{C}$ terminus of the protein that includes a RAD51 interaction site $^{5,27}$. A similar frameshift mutation has been found in multiple Dutch families with breast and ovarian cancer $^{28}$. Brca2 $2^{427 / 427}$ mice are viable and fertile, but show an increased incidence of tumours at long latency compared with wild-type littermates, including mammary ${ }^{27}$. 


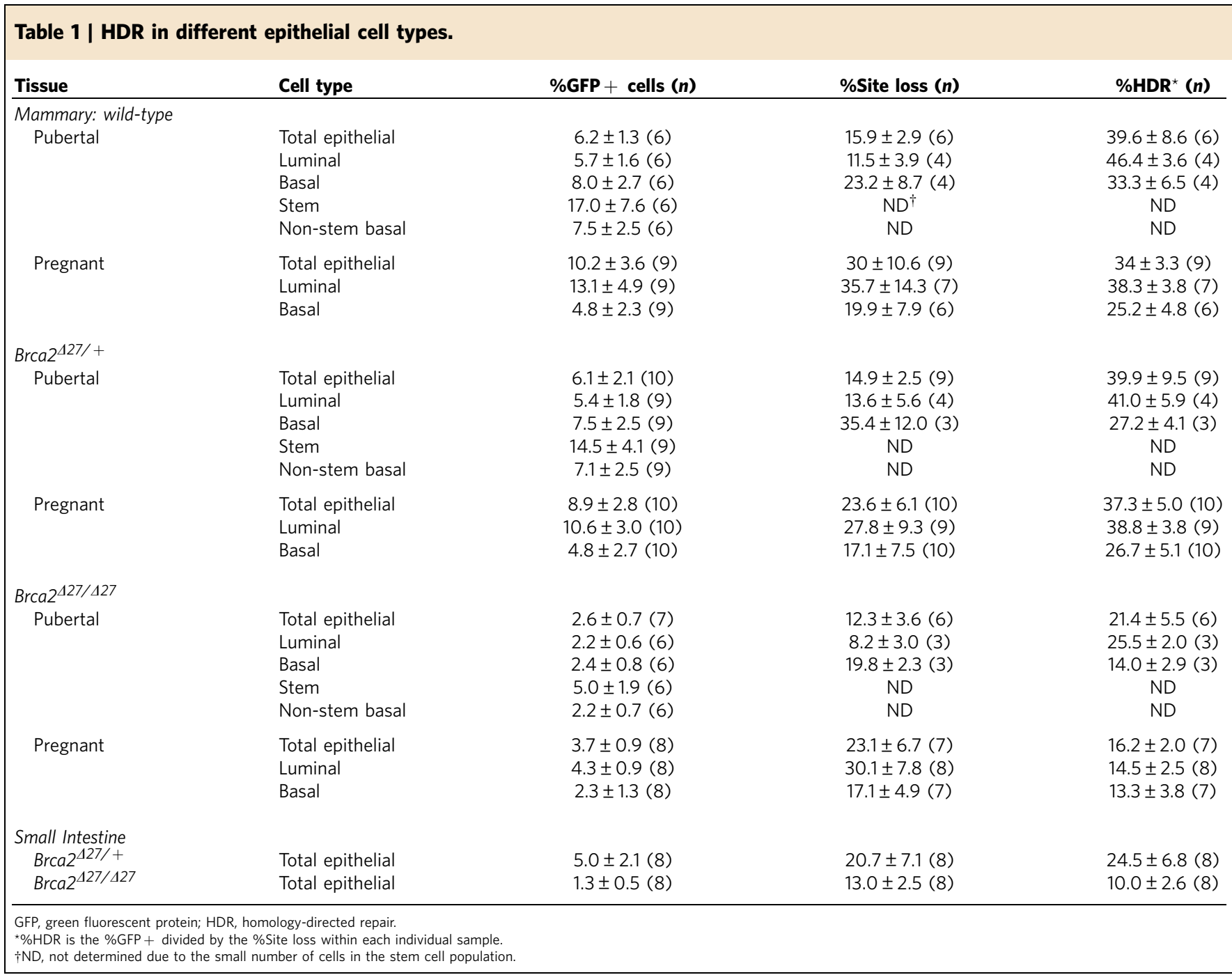

a

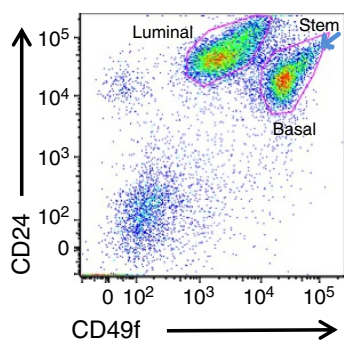

b

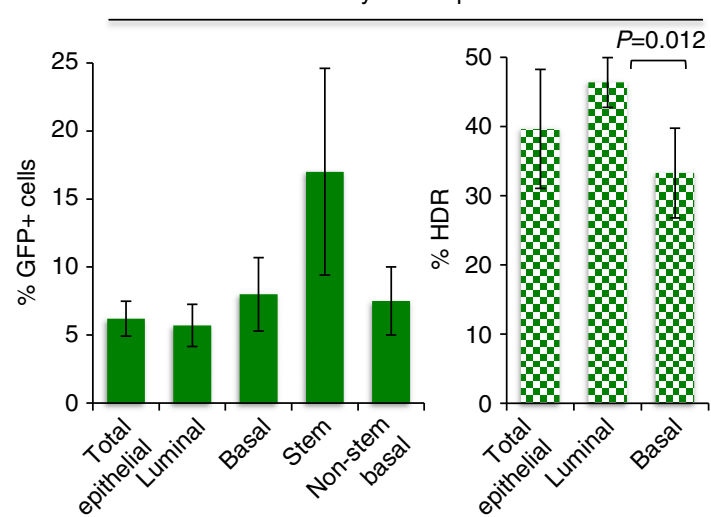

C

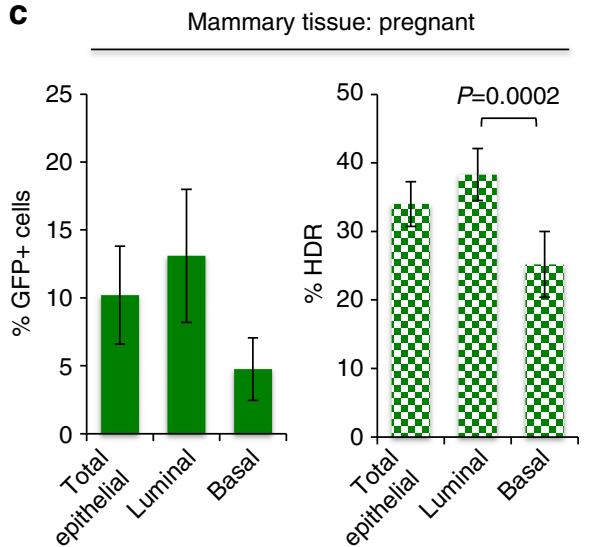

Figure 2 | Dependency on HDR varies in different mammary epithelial cell subpopulations. (a) Representative flow cytometry dot plot of freshly dissociated mammary epithelial cells stained with anti-CD24 and anti-CD49f antibodies to distinguish luminal (CD24 ${ }^{+}$CD49flow) and basal $\left(\mathrm{CD} 24^{+} \mathrm{CD} 49 \mathrm{f}^{\mathrm{h}}{ }^{\mathrm{gh}}\right.$ ) populations. Arrow points to putative stem cell subpopulation (top $5 \%$ of the basal population). (b) Luminal and basal mammary epithelial cells were sorted from wild-type pubertal mice (Fig. 1e,h) and analysed for GFP expression ( $n=6$ mice) and HDR ( $n=4$ mice), as indicated. The $\%$ GFP + cells in the stem and non-stem cell basal populations are shown. (c) Luminal and basal mammary epithelial cells were sorted from wild-type pregnant mice (Fig. 1e,h) and analysed for GFP expression ( $n=9$ mice) and HDR ( $n \geq 6$ mice), as indicated.

Pubertal Brca2 $2^{427 / \Delta 27}$ mice showed no significant alteration in ductal morphology compared with heterozygous littermates (Fig. 3a). Similarly, expansion of the alveolar tree was normal during pregnancy, and $B r c a 2^{427 / \Delta 27}$ mice were able to nurse their pups. Mammary tissue from $\mathrm{BrCa}^{427 / 427}$ and $B r c a 2^{427 /+}$ littermates showed similar staining for the proliferation marker 
a
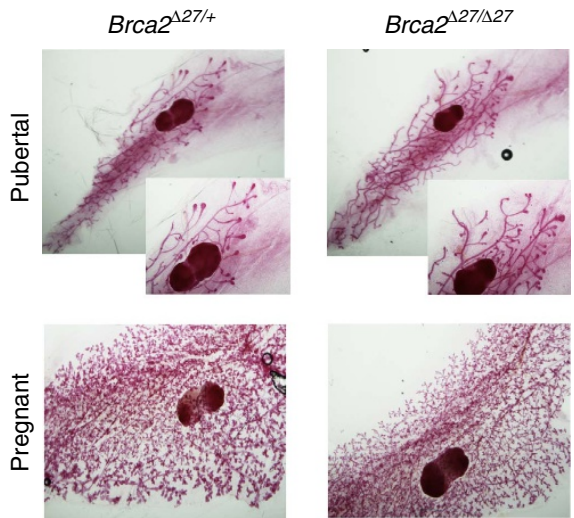

b

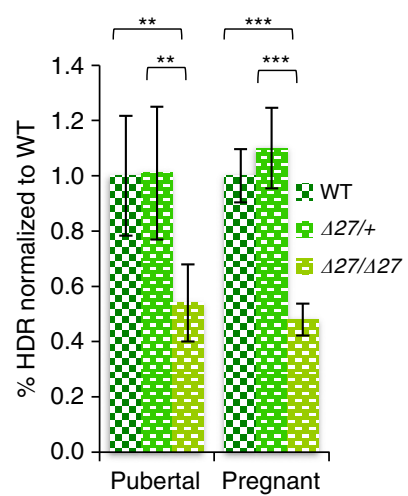

C
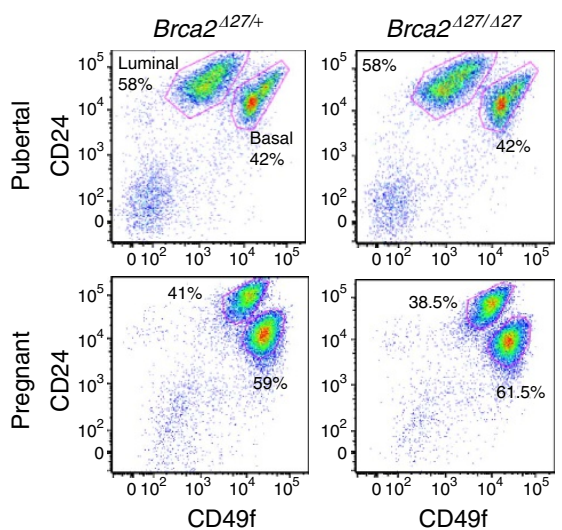

d

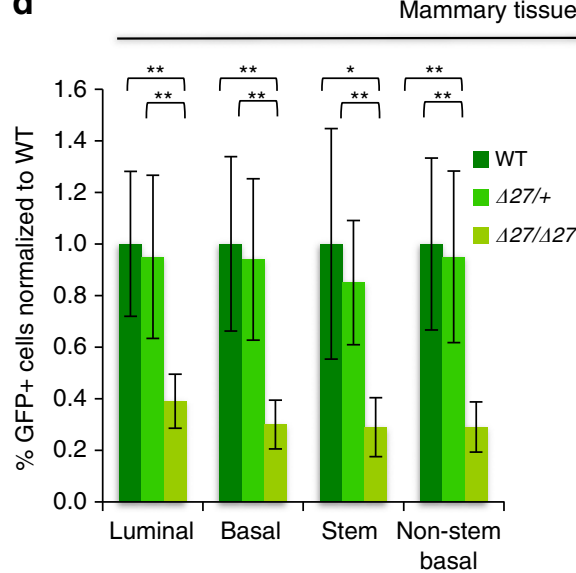

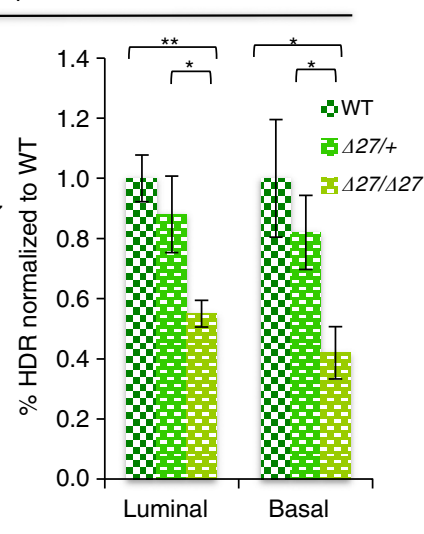

e
Mammary tissue: pregnant

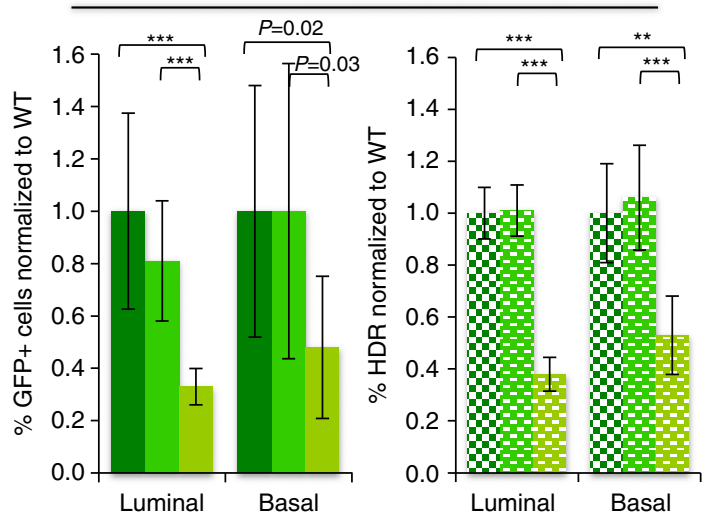

Figure 3 | HDR is reduced in mammary epithelium from $\mathbf{B r c a 2}^{\mathbf{4 2 7} / \Delta 27}$ mice. (a) Representative whole-mount images of carmine alum-stained fourth inguinal mammary glands from 5-week-old Brca2 ${ }^{427 /+}$ and Brca2 ${ }^{427 / 427}$ littermates (top) and pregnant (dpc 15.5) Brca2 $427 /+$ and Brca2 ${ }^{427 / \Delta 27}$ littermates (bottom). (b) HDR in mammary tissue is reduced by Brca2 $2^{427}$ mutation. The \%HDR for Brca2 $2^{427 /+}$ and Brca2 $2^{427 / \Delta 27}$ mammary tissue is shown normalized to WT for pubertal ( $n \geq 6$ mice of each genotype) and pregnant ( $n \geq 7$ mice of each genotype) mice. Mammary epithelial cells were dissociated from freshly harvested tissue from 6-week-old pubertal mice and 14.5-17.5 dpc pregnant mice treated with Dox for 9 days before harvest; ${ }^{\star \star} P \leq 0.001$, ${ }^{\star \star \star} P \leq 0.0001$ (student's $t$-test; two-tailed). (c) Representative flow cytometry dot plots of luminal (CD24 + CD49flow) and basal (CD24 + CD49fhigh) populations from pubertal (6-week old) and pregnant $\operatorname{Brca}^{427 / \Delta 27}\left(14.5 \mathrm{dpc}\right.$ ) mice versus $B r c a 2^{427 /+}$ controls. Values shown for basal and luminal populations are the percentages of the total number of epithelial cells. (d) HDR is reduced in different mammary epithelial cell subpopulations in pubertal $B r c a 2^{427 / \Delta 27}$ mice. Mammary epithelial cells of the indicated populations from pubertal mice (Fig. 3b) were analysed for GFP expression (left). Luminal and basal mammary epithelial cells were sorted and \%HDR for Brca2 ${ }^{427 /+}$ and $B r c a 2^{427 / \Delta 27}$ is shown normalized to WT ( $n \geq 3$ mice of each genotype) for each population (right). ${ }^{\star} P \leq 0.01,{ }^{\star \star} P \leq 0.001$ (student's $t$-test; two-tailed). (e) HDR is reduced in different mammary epithelial cell subpopulations in pregnant Brca $2^{427 / \Delta 27}$ mice. Luminal and basal mammary epithelial cells were sorted from pregnant mice (Fig. 3b) and analysed for GFP expression and HDR, as indicated. Values for Brca2 $2^{427 /+}$ and Brca2 ${ }^{427 / \Delta 27}$ are shown normalized to WT for each population ( $n \geq 6$ mice of each genotype). ${ }^{\star \star} P \leq 0.001,{ }^{\star \star \star} P \leq 0.0001$ (student's $t$-test; two-tailed). The legends for the two panels are the same as the two panels shown in $\mathbf{d}$.

Ki67 (Supplementary Fig. 2a), and the number of S phase cells was similar when mice were pulsed with the thymidine analogue EdU (Supplementary Fig. 2b).

To analyse HDR in the mammary tissue of Brca2 mutant mice, we used the same Dox course described above for wild-type animals. I-SceI expression was similar in mutant and control littermates (Supplementary Fig. 2c), and comparable levels of I-SceI site loss were also observed (Supplementary Fig. $2 \mathrm{~d}$ and Table 1). The number of GFP + cells was found to be significantly reduced in pubertal and pregnant mice with Brca2 mutation compared with wild-type or $\mathrm{BrCa}^{427 /+}$ mice; taking into account I-SceI site loss, the reduction in the per cent HDR was approximately twofold in the mutant animals. (Fig. 3b, Supplementary Fig. 2e and Table 1). Thus, Brca2 truncation at the $\mathrm{C}$ terminus led to a clear defect in HDR in mammary tissue.
$\mathrm{BrCa}^{427}$ mutation reduces HDR in different mammary lineages. We also examined HDR in the different lineages of the mammary gland of the Brca2 mutant mice. The lineage composition of the gland was unaffected in the mutants during puberty or pregnancy (Fig. 3c). During puberty, $\mathrm{BrCa}^{427 / \Delta 27}$ mice showed a similar reduction in the per cent GFP + cells in the luminal and basal populations, resulting in an overall $\sim 2-2.5$-fold reduction in HDR (Fig. 3d and Supplementary Fig. 2f). As in control mice, the stem cell population from $\mathrm{BrCa} 2^{42 \% / 427}$ mice was enriched for GFP + cells, but the mutant stem cells showed a similar reduction compared with non-stem basal or luminal cells. During pregnancy, the percentage of GFP + cells in the luminal or basal populations from $B r c a 2^{427 / \Delta 27}$ mice was also reduced compared with control mice, although to a somewhat larger extent in the luminal compared with basal population (HDR: 2.6-fold versus $\sim 2$-fold, respectively; Fig. 3e and Supplementary Fig. 2g). 
Similar HDR defects in other tissues from $\mathrm{BrCa2}^{427 / 427}$ mice. For comparison with mammary epithelium, we analysed HDR in another highly proliferative tissue, the small intestine. Like the pubertal and pregnant mammary gland, a high percentage of cells in the small intestine are proliferating, as seen by Ki67 staining (Supplementary Fig. 3a) and EdU incorporation $(\sim 12 \%$; Supplementary Fig. 3b). GFP expression is nearly ubiquitous in small intestine cells of mice that constitutionally have a recombined DR-GFP locus (92\%; Supplementary Fig. 3c), as with mammary gland ${ }^{15}$, indicating that GFP expression in these two tissues is comparable once HDR has occurred. I-SceI was readily detected in the small intestine epithelium of I-SceI DR-GFP mice treated with the same 9-day course of Dox (Fig. 4a).

GFP + cells were observed dispersed throughout the epithelium with Dox treatment (Fig. 4b). To quantify HDR, epithelial sheets were isolated and then dissociated into single cell suspensions for flow cytometry. A slightly lower fraction of GFP + cells was observed in the intestinal epithelial cells compared with the mammary gland but was still substantial (5\%; Supplementary Fig. $3 \mathrm{~d}$ and Table 1). Considering the observed I-SceI site loss (21\%), the overall level of HDR was estimated to be $24.5 \%$ (Fig. $4 \mathrm{c}$ ). We also examined the small intestine epithelium of $\mathrm{BrCa}^{427 / \Delta 27}$ mice. HDR was reduced 2.5-fold relative to $B r c a 2^{427 /+}$ mice (Fig. $4 \mathrm{~d}$ ), similar to that seen in mammary epithelium of both pubertal and pregnant mice.

HDR in total bone marrow was also analysed. Fewer I-SceI-expressing cells were observed in bone marrow (Supplementary Fig. 3e). Taking into account the lower expression and site loss $(\sim 11 \%)$, the overall per cent HDR in control animals was only $\sim 8 \%$ (Fig. $4 \mathrm{c}$ and Supplementary Fig. 3f). However, in BrCa2 $2^{427 / 427}$ animals, bone marrow showed a similar reduction in HDR as in the mammary and small intestine epithelium (Fig. 4d). Thus, Brca2 mutation does not lead to a mammary tissue-specific defect in HDR but rather diminishes HDR in multiple tissue types, including mammary, hematologic and intestinal tissues.

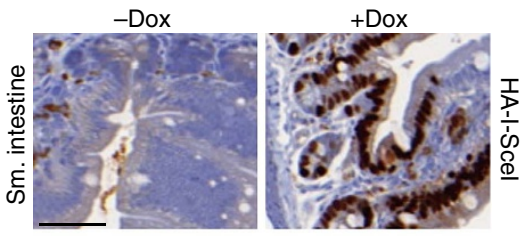

b

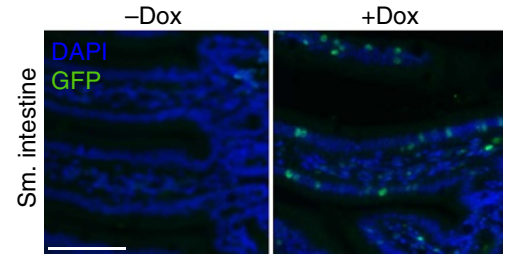

C

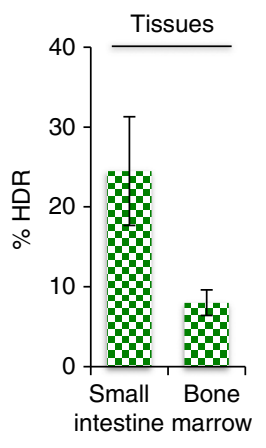

d

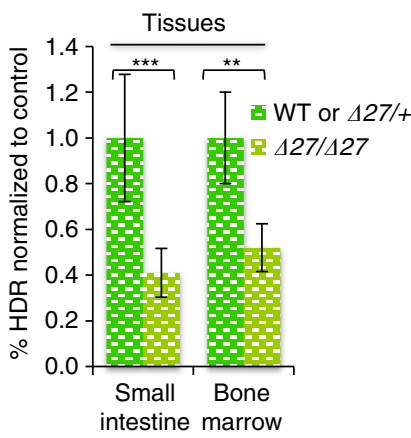

g

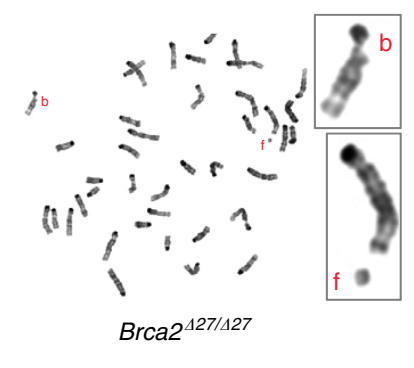

e

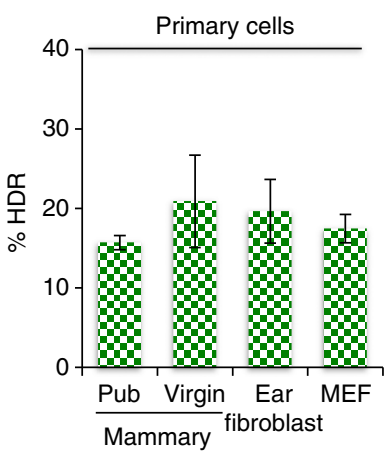

f

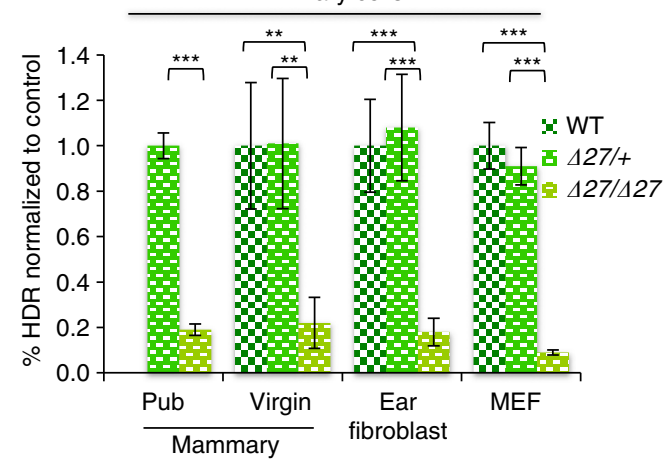

Primary cells

Figure 4 | Brca2 ${ }^{\mathbf{L 2 7}}$ mutation reduces HDR similarly in other tissues and different primary cell types. (a) Immunohistochemistry staining of small intestine tissue sections with an anti-HA antibody demonstrating Dox-dependent I-Scel expression. Staining in the absence of Dox is due to antibody trapping since I-Scel is a nuclear protein. Scale bar, $50 \mu \mathrm{m}$. (b) Representative immunofluorescence image demonstrating HDR events after Dox treatment in small intestine epithelium using an anti-GFP antibody. Nuclei are visualized by DAPI. Scale bar, $100 \mu \mathrm{m}$. (c) HDR in other proliferative tissues. Small intestinal epithelial cells were harvested from 6 to 9 -week-old male and female Brca2 $2^{\Delta 27 /+}$ mice $(n=8)$ following a 9 day course of Dox. Total bone marrow was harvested from 6-week-old female Brca2 ${ }^{+/+}$and Brca2 $427 /+$ mice $(n=7)$. (d) HDR is reduced in other tissues in Brca2 $427 / \Delta 27$ mice. The $\% H D R$ in small intestine epithelium $(n=8)$ and total bone marrow $(n=5)$ from Brca ${ }^{427 / \Delta 27}$ mice is shown normalized to controls. ${ }^{\star \star} P \leq 0.001$,

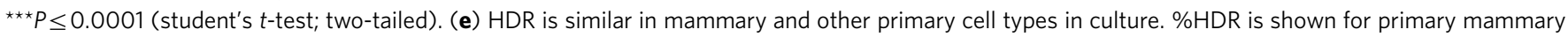

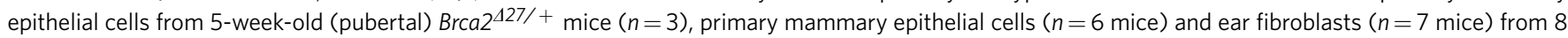
to 12 -week-old adult virgin wild-type mice and primary embryonic fibroblasts from E14.5 wild-type embryos ( $n=5$ embryos). (f) Brca2 427 mutation substantially reduces HDR in primary mammary epithelial cells and other cell types. The \%HDR in primary mammary epithelial cells ( $n \geq 4$ mice) and ear fibroblasts ( $n \geq 7$ mice) from adult virgin Brca2 $427 /+$ and Brca2 $2^{427 / \Delta 27}$ mice and MEFs ( $n \geq 3$ embryos) from E14.5 Brca2 $2^{427 /+}$ and Brca2 $427 / 427$ embryos is shown normalized to WT for each cell type. The \%HDR in primary mammary epithelial cells ( $n=3$ mice) from Brca $2^{427 / \Delta 27}$ pubertal mice is shown normalized to Brca2 ${ }^{427 /+}$ controls. See Supplementary Data 1 for specific $n$ for each genotype. ${ }^{\star \star} P \leq 0.001$, ${ }^{\star \star \star} P \leq 0.0001$ (student's $t$-test; two-tailed). (g) Metaphase spread with representative aberrations (insets) from primary mammary epithelial cells derived from Brca $2^{427 / \Delta 27}$ mice showing a chromatid break (b) and a chromosome fragment (f) adjacent to a normal chromosome. 
$\mathrm{BrCa}^{427}$ mutation substantially reduces HDR in primary cells. In addition to tissues within the animal, we also examined HDR in primary cells to determine how well results from cultured cells would correlate with those in the animal. Following Dox treatment, I-SceI site loss was extremely high at $\sim 40 \%$ in mammary epithelial and fibroblast cultures, and substantial numbers of GFP + cells were observed $(\sim 8-10 \%$, Supplementary Fig. 4a). Overall, HDR accounted for $\sim 20 \%$ of repair events in all cell types, including primary mammary epithelial cells from pubertal and adult virgin mice (Fig. 4e). This is significantly lower than that observed in the pubertal mammary tissue itself, illustrating that culture conditions do not recapitulate the normal tissue milieu.

Primary mammary epithelial cells derived from $\mathrm{BrCa}^{427 / \Delta 27}$ pubertal or adult virgin mice and ear fibroblasts were found to have an approximately fivefold reduction in HDR; primary embryonic fibroblasts (MEFs) showed an even larger reduction (11-fold; Fig. 4f and Supplementary Fig. 4a), as they did when I-SceI was expressed from a transfected vector rather than induced with Dox (Supplementary Fig. 4b). Not surprisingly, given the substantial HDR defect, the primary $\mathrm{Brca}^{4277427}$ mammary cells presented with a high number of chromosome aberrations, especially chromatid breaks (Fig. $4 \mathrm{~g}$ and Supplementary Fig. 4c). The $S$ phase population was found to be reduced only $\sim 20 \%$ in the $\mathrm{BrCa}^{4277 \Delta 27}$ cells compared with controls (Supplementary Fig. 4d), which alone seems unlikely to account for the much greater HDR defect seen in culture, although it suggests that the mutant cells are under stress, even at very low passage. Thus, a similar HDR defect is observed with Brca2 mutation in both mammary and fibroblast cultures, consistent with the lack of a mammary cell-specific effect. Interestingly, the defect observed in culture is larger than that observed in the animal, even for cells derived from the same tissue (that is, pubertal mammary epithelial cells had fivefold reduced HDR in culture compared with twofold within the gland). Whether the normal tissue environment minimizes the effect of HDR gene mutation or the abnormal culture condition exacerbates HDR defects is not clear.

\section{Discussion}

The importance of HDR in the animal has been unclear. Prior estimates have suggested low levels of HDR in tissues ${ }^{29}$, or were inferred from indirect measures, such as toxicity after exposure to DNA damaging agents and DNA damage-induced foci formation ${ }^{30,31}$. The efficient induction of a DNA lesion at a defined genomic location is a powerful approach to understanding DNA repair, and specifically HDR, within the organism. HDR is expected to be highest when cells are cycling, and although many adult tissues are not highly proliferative, cells do proliferate during developmental periods and for self-renewal and wound healing. In particular, the mammary gland undergoes significant proliferative changes after birth and is at risk for tumour development when HDR genes are mutated ${ }^{6}$.

To address the contribution of HDR, we have developed an approach to interrogate DNA repair within the organism by inducing a DSB at a defined genomic location within the context of an HDR reporter. With this approach, DSB induction in proliferating mammary tissue is efficient as is repair by HDR. In keeping with the cell cycle preference for HDR, events are enriched in S/G2 phase cells. A large fraction of detected DSB repair events in pubertal or pregnant mammary epithelium arise from HDR (34-40\%), providing quantitative evidence that HDR is a major DSB repair pathway in this tissue.

A significant advantage of our mouse model, with particular relevance to the mammary gland, is the ability to identify specific epithelial cell populations that have undergone HDR, since different cell lineages may have different DNA repair capacities which could impact tissue development and tumour predisposition. During puberty, HDR is greater in the luminal population than in the basal population, in keeping with its larger fraction of proliferative cells ${ }^{32}$. Etiologically, luminal cells contribute to the predominant types of human breast tumours ${ }^{33}$. Notably, however, the highest levels of GFP + cells in the pubertal gland are in the putative stem cells, a small population identified based on cell surface marker expression. During pregnancy, a significantly larger number of GFP + cells were observed in the luminal population, such that HDR was $\sim 1.5$-fold greater than in the basal population. Studies have suggested the existence of pregnancy-specific multipotent progenitors that may control alveolar expansion ${ }^{34-36}$, and these progenitors are thought to be in the luminal population ${ }^{34}$.

The small intestine epithelium also showed substantial HDR, although not as high as that in the proliferative mammary epithelium. It will be interesting to determine if HDR varies within lineages in the small intestine epithelium. The higher level measured in mammary tissue suggests that the hormonedependent proliferative stages of mammary gland development may have greater utilization of HDR compared with other tissues, such that HDR gene mutations compromise genomic integrity more in mammary tissue than other tissue types.

BRCA2, together with BRCA1, are the most frequently mutated HDR genes in breast cancers ${ }^{6}$. The mouse Brca2 $^{427}$ hypomorphic mutation models a truncation mutation found in multiple families with breast and ovarian cancer ${ }^{28}$. Mammary tissue during puberty and pregnancy from these mice have a similar two-three-fold HDR defect as in other proliferative tissue types, including small intestine epithelium, suggesting that an HDR defect per se may not confer tissue specificity for BRCA2-associated breast cancers. Our results instead suggest that a greater reliance on HDR to repair DSBs may magnify the effect of BRCA2 deficiency, making the mammary epithelium more predisposed to tumorigenesis. Whether an increased reliance on $\mathrm{HDR}$ is due to cycles of proliferation leading to replication-associated DNA damage and possibly other sources of DNA damage, as from estrogen ${ }^{37,38}$, is unclear.

It is notable that while breast and ovarian cancers are particularly prevalent, $B R C A 2$ mutation carriers are predisposed at lower penetrance to a range of cancers, including pancreas and prostate $e^{5}$. Further, young children with biallelic BRCA2 mutations are at high risk for several tumour types including of the brain, which is still undergoing significant levels of proliferation during childhood ${ }^{39}$. Thus, the requirement for BRCA2 in HDR in other tissues is consistent with BRCA2 mutations impacting tumour predisposition in multiple tissue types. Clearly, however, other factors besides HDR levels are likely to affect tumour predisposition in any particular cell type; for example, it has been argued that cell turnover can protect the small intestine from tumorigenesis resulting from BRCA2 deficiency 40

Although not as dramatic as with pregnancy, the mammary gland undergoes continuing cycles of hormone-driven proliferation during each estrous cycle throughout a woman's reproductive lifespan. Further, proliferation that occurs during pregnancy and each estrous cycle is followed by extensive tissue remodelling to restore the gland to a ground state ${ }^{41}$. Thus, it seems possible that the recurrent, developmental changes may alter the DSB repair-associated effects of BRCA2 mutation over a lifetime. Even when extensive remodelling occurs, not all cells are likely to be eliminated.

Determining how BRCA mutations affect the repair proficiencies of specific mammary epithelial subpopulations is 
relevant to understanding the cell-of-origin of breast cancers ${ }^{42}$. Since the requirement for BRCA2 for efficient HDR is thought to be central to its tumour suppressor role, our observation that $\mathrm{BrCa}^{427}$ mutation reduced HDR similarly in each of the mammary epithelial cell subpopulations analysed suggests that multiple possible cells-of-origin for mammary tumours are at risk with BRCA2 mutation, consistent with the heterogeneous nature of BRCA2-associated breast cancers. The finding of high numbers of GFP + cells in the pubertal mammary stem cell population, although not fully interrogated for HDR contribution by site loss determination, suggests that the genomic instability incurred in these cells as a result of BRCA2 deficiency would be propagated to both luminal and basal daughter cells, which would also contribute to tumour heterogeneity. Given that BRCA1associated tumours have a more defined cell origin ${ }^{43,44}$, it will be interesting to determine whether HDR is affected in specific lineages with BRCA1 deficiency.

\section{Methods}

Mice. Animal care and all animal experiments were performed with the approval of the Memorial Sloan Kettering Cancer Center (MSKCC) IACUC. Mice were housed in the animal facility at MSKCC in accordance with institutional guidelines with 12-hour light and 12-hour dark cycles. I-SceI expression was induced in mice by administering $3 \mathrm{mg} \mathrm{ml}^{-1}$ Dox in drinking water with $5 \%$ sucrose. Dox water was replaced every $72 \mathrm{~h}$ over a 9-day course. For timed mating, the day of vaginal plug detection was designated $0.5 \mathrm{dpc}$. CMV-rtTA transgenic mice and the $P_{i m} 1^{D R-G F P}$ and $\mathrm{BrCa}^{227}$ alleles have been described ${ }^{15,19,27}$. Mice were maintained on a mixed genetic background.

For genotyping, genomic DNA was extracted from tail tips using the Gentra Puregene kit (Qiagen) following the manufacturer's protocol. PCR reactions were performed with 100 ng genomic DNA and 15 pmole of each primer using PuReTaq PCR beads (GE Healthcare). DR-GFP mice were genotyped using primers Pim1Ex1F 5'-AAGATCAACTCCCTGGCCCACCTGCG-3'; Pim1Ex4R 5'-TGTT CTCGTCCTTGATGTCG- $3^{\prime}$ and Hyg 3 A $5^{\prime}$-CCGCTCGTCTGGCTAAGAT- $3^{\prime}$ and the following conditions: $94^{\circ} \mathrm{C}$ for $3 \mathrm{~min} ; 35$ cycles of $94^{\circ} \mathrm{C}$ for $45 \mathrm{~s}, 62.9^{\circ} \mathrm{C}$ for $45 \mathrm{~s}$ and $72{ }^{\circ} \mathrm{C}$ for $1 \mathrm{~min}$ and a final extension step at $72{ }^{\circ} \mathrm{C}$ for $15 \mathrm{~min}$. PCR products (786 bp for wild-type allele and $958 \mathrm{bp}$ for the targeted allele) were separated by electrophoresis on a $1.2 \%$ agarose gel. The CMV-rtTA transgene was detected using rtTA-specific forward primer 5'-GCTTGGTGTAGAGCAGCCTACAC- ${ }^{\prime}$ and reverse primer $5^{\prime}$-CAGCGCTGAGTGCATATAACGCG- $3^{\prime}$ and the following conditions: $94^{\circ} \mathrm{C}$ for $4 \mathrm{~min} ; 35$ cycles of $94^{\circ} \mathrm{C}$ for $30 \mathrm{~s}, 55^{\circ} \mathrm{C}$ for $30 \mathrm{~s}$ and $72^{\circ} \mathrm{C}$ for $30 \mathrm{~s}$ and a final extension step at $72^{\circ} \mathrm{C}$ for $7 \mathrm{~min}$ (ref. 19). An $\sim 310 \mathrm{bp}$ product indicates presence of the transgene. $\mathrm{Brca} 2^{427}$ mice were genotyped using primers B2F 5'- GGAGGAGGAGGAGTTGTTGA-3'; B2R1.WT 5'-GTCCGGCAGAGAA ACGCCACTG- $3^{\prime}$ and B2R2.MUT $5^{\prime}$-CAAAAAAGCCCAGATGATGAG- $3^{\prime}$ and the following conditions: $94^{\circ} \mathrm{C}$ for $2 \mathrm{~min} ; 30$ cycles of $94^{\circ} \mathrm{C}$ for $1 \mathrm{~min}, 65^{\circ} \mathrm{C}$ for $1 \mathrm{~min}$ and $72{ }^{\circ} \mathrm{C}$ for $1 \mathrm{~min}$ and a final extension step at $72{ }^{\circ} \mathrm{C}$ for $7 \mathrm{~min}$. PCR products ( $~ 930 \mathrm{bp}$ for wild-type allele and $680 \mathrm{bp}$ for the mutant allele) were separated by electrophoresis on a $1.2 \%$ agarose gel.

Generation of inducible I-Scel mice. A linearized $1.5 \mathrm{~kb}$ fragment of DNA containing seven direct repeats of the tet operator sequence and I-SceI-coding sequence excised from pWHE-320-HA-I-SceI (ref. 45) by AvaI digestion was injected into fertilized F2 eggs obtained from mating of (C57BL/6J $\times \mathrm{CBA} / \mathrm{J}) \mathrm{F} 1$ mice (Supplementary Fig. 1a). Genomic DNA was extracted from tail tips of 66 pups, digested with BsrGI and analysed for the presence of the TRE-I-SceI transgene by Southern blot analysis using a tet-operon-specific probe (Supplementary Fig. 1b). Three TRE-I-SceI founder lines were identified. Two lowcopy TRE-I-SceI founders gave rise to lines with robust, controlled expression of I-SceI (Supplementary Fig. 1c). Line \#10 was chosen for use in all subsequent analyses. The insertion site for the TRE-I-SceI transgene in the Founder 10 line was mapped to Chromosome 6 by chromosome walking using the GenomeWalker Universal kit (Clontech), and it was found that the transgene locus could be bred to homozygosity, consistent with its benign genomic location (Supplementary Fig. 1c,d). Founder 10 I-SceI mice were genotyped using primers F10.For.Chr6 5'-CTACATGTGGCAACTGGCTCAATCA-3'; F10.Rev.350 5'-CTGAGCCATC TCTCTAGCCCA- $3^{\prime}$ and SCE.Rev $5^{\prime}$-CTGCTTATATAGGCCTCCCACCGTA CA- $3^{\prime}$ and the following conditions: $95^{\circ} \mathrm{C}$ for $3 \mathrm{~min} ; 32$ cycles of $95^{\circ} \mathrm{C}$ for $30 \mathrm{~s}$, $58.5^{\circ} \mathrm{C}$ for $30 \mathrm{~s}$ and $72^{\circ} \mathrm{C}$ for $1 \mathrm{~min}$ and a final extension step at $72^{\circ} \mathrm{C}$ for $5 \mathrm{~min}$. PCR products ( $350 \mathrm{bp}$ for wild-type band and $550 \mathrm{bp}$ for I-SceI) were separated by electrophoresis on a $1.5 \%$ agarose gel.

Mammary epithelial cell purification and flow cytometry. For tissue experiments, all mice were homozygous for the TRE-I-SceI transgene. Fourth inguinal mammary glands were dissected from 6-week-old female mice for puberty, and P14.5-17.5 at 10-13 weeks of age for pregnancy experiments. Lymph nodes were removed, and fresh tissue was minced with a razor blade and incubated for $1 \mathrm{~h}$ at $37^{\circ} \mathrm{C}$ with gentle shaking in DMEM/F12 containing $2 \mathrm{mg} \mathrm{ml}^{-1}$ collagenase (Roche) and a mixture of $33 \mathrm{U} \mathrm{ml}^{-1}$ hyaluronidase and $100 \mathrm{U} \mathrm{ml}^{-1}$ collagenase (StemCell Technologies, Inc.) with $5 \mu \mathrm{g} \mathrm{ml}^{-1}$ insulin. Organoids were isolated by differential centrifugation and were dissociated in $0.2 \%$ trypsin-EDTA for $5 \mathrm{~min}$ followed by $5 \mathrm{U} \mathrm{ml}^{-1}$ dispase (StemCell Technologies, Inc.) with $0.1 \mathrm{mg} \mathrm{ml}^{-1}$ DNase I (StemCell Technologies, Inc.) for $5 \mathrm{~min}$. Cells were filtered through a $40 \mu \mathrm{m}$ cell strainer, and negative selection against $\mathrm{Lin}^{+}$cells was done using the EasySep Mouse Epithelial Cell Enrichment kit (Stem Cell Technologies). Lin $^{-}\left(\mathrm{CD} 45^{-} \mathrm{CD} 31^{-}\right.$TER119- $\left.\mathrm{BP}-1^{-}\right)$cells were blocked for $10 \mathrm{~min}$ on ice in Hank's balanced salt solution (HBSS) containing $10 \mathrm{mM}$ HEPES and $10 \%$ fetal bovine serum (FBS) followed by immunostaining for $10 \mathrm{~min}$ on ice in HBSS containing $10 \mathrm{mM}$ HEPES and 2\% FBS with PE/Cy7 anti-mouse CD24 (1:400, BioLegend, 101821) and Alexa Fluor 647 anti-human/mouse CD49f (1:100, BD Biosciences, 562473) antibodies. Cells were filtered through a strainer cap and analysed on a BD FACScan or for sorting experiments dead cells were excluded by DAPI staining and cell populations were sorted using a BD FACS ARIA.

In vivo EdU incorporation. For analysis of EdU incorporation in GFP + cells, mice on a 3-day course of $3 \mathrm{mg} \mathrm{ml}^{-1}$ Dox in drinking water received a single intraperitoneal injection of $0.5 \mathrm{mg}$ EdU in PBS per $10 \mathrm{~g}$ mouse weight. After $24 \mathrm{~h}$, mice were killed, and mammary epithelial cells were dissociated from freshly harvested tissue. Single cells were fixed with $4 \%$ paraformaldehyde (PFA), stained using the Click-iT Plus EdU Alexa Fluor 647 Flow Cytometry assay kit (ThermoFisher Scientific) and analysed on a BD LSRFortessa. For experiments comparing EdU incorporation in mammary epithelial cells versus small intestine epithelial cells, mice received a single intraperitoneal injection of $0.5 \mathrm{mg}$ EdU in PBS per $10 \mathrm{~g}$ mouse weight, and were killed after $24 \mathrm{~h}$ and analysed as above. For experiments comparing EdU incorporation in mammary epithelial cells from Brca2 mutant mice versus heterozygous controls, mice received a single intraperitoneal injection of $0.3 \mathrm{mg}$ EdU in PBS per $10 \mathrm{~g}$ mouse weight. After $3 \mathrm{~h}$, mice were killed and mammary epithelial cells were dissociated from freshly harvested tissue, fixed with 4\% PFA, stained using the Click-iT EdU Alexa Fluor 488 Flow Cytometry assay kit (ThermoFisher Scientific) and analysed on a BD FACScan.

I-Scel site loss assays. To estimate the efficiency of I-Scel cleavage, cells were collected at the same time as for flow cytometry for DNA extraction using the Puregene Core Kit A (Qiagen). Sequences flanking the I-SceI site were amplified with forward primer $5^{\prime}$-CCCGCCACCTGCCCCATCTGCTA and reverse primer $5^{\prime}$-CCTCTACAAATGTGGTATGGCTGATTATG. PCR products were cleaved in vitro with I-Scel (Fermentas) and run on a $1.5 \%$ agarose gel. The intensity of the uncleaved ( $879 \mathrm{bp}$ ) and cleaved (663 bp) bands were quantified using a BioRad ChemiDoc System with rolling disk background subtraction. Because the $663 \mathrm{bp}$ band is less intense than the $879 \mathrm{bp}$ band, a $1.325(879 \mathrm{bp} / 663 \mathrm{bp})$ correction factor was used to calculate the site loss fraction (intensity of the $879 \mathrm{bp}$ band divided by (intensity of the $879 \mathrm{bp}$ band plus intensity of the $663 \mathrm{bp}$ band multiplied by 1.325 )).

Histological analysis. The fourth inguinal mammary glands and segments of the small intestine (duodenum, jejunum) were resected and fixed overnight in $4 \%$ PFA and stored in 70\% ethanol. PFA-fixed tissues were paraffin embedded and $5 \mu \mathrm{m}$ sections were used for immunohistochemistry with anti-HA $\left(1 \mu \mathrm{g} \mathrm{ml}{ }^{-1}\right.$; Roche, $11867431001)$ and anti-Ki67 $\left(0.4 \mu \mathrm{g} \mathrm{ml}^{-1}\right.$; Vector, VP-K451) antibodies or immunofluorescence with anti-GFP $\left(2 \mu \mathrm{g} \mathrm{ml}^{-1}\right.$; abcam, ab13970) and anti-CK8 (TROMA-1; 1:100; Developmental Studies Hybridoma Bank) or anti-CK14 (LL002; $1 \mu \mathrm{g} \mathrm{ml}^{-1}$; abcam, ab7800) antibodies.

Mammary gland whole mounts. The fourth inguinal mammary glands were dissected, spread onto slides and fixed in Carnoy's fixative overnight. Tissues were rehydrated in successive washes of 70, 50, 30 and $10 \% \mathrm{EtOH}$ then washed in distilled $\mathrm{H}_{2} \mathrm{O}$ and stained overnight in carmine alum solution (Stem Cell Technologies). After staining, mammary glands were washed successively in 70, 95 and $100 \% \mathrm{EtOH}$, cleared overnight in xylene and mounted in Permount (Fisher).

Isolation of small intestine epithelial cells. Epithelial cells were isolated from the small intestine. Briefly, a $2 \mathrm{~cm}$ segment of the duodenum was longitudinally cut open and lightly rinsed with PBS to remove residual luminal contents. The tissue was incubated in $5 \mathrm{ml} 20 \mathrm{mM}$ EDTA in PBS at $37^{\circ} \mathrm{C}$ for $5 \mathrm{~min}$ and then shaken. After shaking, the separated muscle layer was removed and the supernatant containing epithelial sheets was centrifuged at $1,000 \mathrm{~g}$ for $1 \mathrm{~min}$. The pelleted epithelial sheet was washed with $10 \%$ FBS in PBS and centrifuged again at $1,000 \mathrm{~g}$ for $1 \mathrm{~min}$. The cells were then resuspended in $2.5 \mathrm{ml}$ of $5 \mathrm{U} \mathrm{ml}^{-1}$ dispase (StemCell Technologies, Inc.) with $50 \mu \mathrm{l}$ of DNaseI (StemCell Technologies, Inc.) and incubated at $37^{\circ} \mathrm{C}$ for $10 \mathrm{~min}$ with intermittent shaking ( $15 \mathrm{~s}$ shaking every $2 \mathrm{~min}$ ) Completion of single cell segregation was confirmed with a hemocytometer. Cells were then filtered through a $70-\mu \mathrm{m}$ filter and centrifuged at $200 \mathrm{~g}$ for $5 \mathrm{~min}$. The resulting pellet was resuspended in $1 \mathrm{ml}$ of HBSS containing $10 \mathrm{mM}$ HEPES 
and $10 \%$ FBS and blocked on ice for $10 \mathrm{~min}$. Cells were then pelleted at $500 \mathrm{~g}$ for 5 min at $4{ }^{\circ} \mathrm{C}$ and resuspended in HBSS containing $10 \mathrm{mM}$ HEPES and 2\% FBS and incubated on ice for 10 min with PE/Cy7 anti-mouse EpCAM antibody (1:200; BioLegend, 118215). After washing one time, cells were resuspended in $1 \mathrm{ml}$ of HBSS containing $10 \mathrm{mM}$ HEPES and 10\% FBS, filtered through a cell strainer cap and analysed on a BD FACScan. EpCAM staining was used to check the purity of each intestine cell preparation, which was similar in $\mathrm{Brca} 2$ mutant and control mice $(\sim 80 \%$; Supplementary Data 1$)$.

Bone marrow harvest. Bone marrow cells were isolated from the femurs of 6-7-week-old female mice. Skin and muscle surrounding the bone was removed and each femur was placed in a PCR tube with a hole in the bottom within a microfuge tube to collect cells following a brief spin. Pelleted cells were treated with red blood cell lysis buffer (Sigma) for $5 \mathrm{~min}$ on ice to eliminate red blood cells. After a brief spin, cells were resuspended in PBS, and GFP expression was analysed on a BD FACScan. Note that slightly reduced GFP expression was observed in bone marrow from recombined DR-GFP mice (76\%; Supplementary Fig. $3 \mathrm{~g}$ ), compared with mammary and intestinal epithelial cells.

Primary cell cultures. All mice used in HDR experiments were hemizygous for the DR-GFP reporter and the CMV-rtTA transgene. Mice were typically hemizygous for the TRE-I-SceI transgene, except where indicated. Mammary epithelial cells were isolated from the fourth inguinal mammary glands of 8-12-week-old virgin female mice and plated in DMEM/F12 containing 10\% FBS supplemented with $10 \mu \mathrm{g} \mathrm{ml}^{-1}$ insulin and $5 \mathrm{ng} \mathrm{ml}^{-1}$ epidermal growth factor. On day 1 after harvest, 150,000 cells were plated in a six-well collagen-coated dish and $18 \mathrm{~h}$ after plating, Dox was added to cells at a concentration of $1 \mu \mathrm{g} \mathrm{ml}^{-1}$ to induce I-SceI expression. Cells were harvested for flow cytometry and genomic DNA extraction $48 \mathrm{~h}$ later.

Primary fibroblasts were obtained from ears of 2-3-month-old freshly killed mice. Ear tissue was clipped at the base of the ear after soaking in $70 \%$ ethanol. Tissues were diced in a Petri dish using a sterile razor, placed into $5 \mathrm{ml}$ of $3 \mathrm{mg} \mathrm{ml}^{-1}$ collagenase solution in DMEM and incubated for $3 \mathrm{~h}$ at $37^{\circ} \mathrm{C}$ with agitation and filtered through a $70 \mu \mathrm{m}$ cell filter. The filtrate was spun at $400 \mathrm{~g}$ for $10 \mathrm{~min}$, and the cell pellet was resuspended in DMEM with $10 \%$ FBS, $1 \%$ penicillin-streptomycin (Gemini), and 1\% MEM nonessential amino acids (Gibco). On day 2 after harvest, 150,000 cells were plated in a six-well dish and $18 \mathrm{~h}$ after plating, Dox was added as above. MEFs were derived from 14.5-days embryos (all embryos were homozygous for TRE-I-SceI). Head and liver were removed, and trunks were minced with a sterile razor blade and dissociated in $1 \mathrm{ml}$ of $0.05 \%$ trypsin/EDTA at $37^{\circ} \mathrm{C}$ for $45 \mathrm{~min}$ followed by pipetting up and down several times in $4 \mathrm{ml}$ high-glucose DMEM with $10 \%$ FBS and filtering through a $70 \mu \mathrm{m}$ cell filter. The filtrate was spun at $400 \mathrm{~g}$ for $5 \mathrm{~min}$, and the cell pellet was resuspended in high-glucose DMEM with 10\% FBS. On day 1 after harvest, 125,000 cells were plated in a six-well dish and Dox was added as above.

Chromosome analysis. Primary mammary epithelial cells at passage 1 were treated with $100 \mathrm{ng} \mathrm{ml}^{-1}$ KaryoMAX Colcemid (ThermoFisher Scientific) for $1 \mathrm{~h}$ before harvest. Following trypsinization, cells were incubated for $15 \mathrm{~min}$ in hypotonic solution $(0.075 \mathrm{M} \mathrm{KCl})$, fixed in methanol:acetic acid (3:1), and spotted onto slides. For each sample, 100 DAPI-banded metaphases were imaged to assess chromosomal instability in the form of chromatid breaks, exchanges and radial figures, ring chromosomes, di- and tricentrics and acentric fragments. Chromatid breaks were counted as single-break events, tri-radials and quadri-radials as two break events each. Chromosome aberrations (acentric fragments, di- and tricentrics, ring chromosomes and marker chromosomes) were recorded and the breaks required for these rearrangements were not added to the frequency of chromatid breaks.

Cell cycle analysis. For cell cycle analysis, primary cells were collected $48 \mathrm{~h}$ after plating for HDR assays ( $24 \mathrm{~h}$ before fluorescent-activated cell sorting (FACS)) while cells are actively cycling. Cells were washed twice with PBS and pelleted by centrifugation at $250 \mathrm{~g}$ for $5 \mathrm{~min}$. Cells were fixed in ice cold $70 \%$ ethanol and kept at $-20^{\circ} \mathrm{C}$ until staining (2-7 days). At the time of staining, the fixed cells were washed twice in $2 \mathrm{ml}$ PBS and then resuspended in $0.2 \mathrm{ml}$ staining buffer containing $20 \mu \mathrm{g} \mathrm{ml}^{-1}$ propidium iodide (PI) and $0.2 \mathrm{mg} \mathrm{ml}^{-1}$ RNaseA with $0.1 \%$ Triton X-100 in PBS.

Western blot analysis. To detect I-SceI expression, cells were collected at the time of FACS analysis ( $48 \mathrm{~h}$ after addition of doxycycline). Cells were lysed for $20 \mathrm{~min}$ on ice in TEGN buffer (10 mM Tris (pH 8), $1 \mathrm{mM}$ EDTA, $10 \%$ glycerol, $0.5 \%$ Nonidet P-40, $400 \mathrm{mM} \mathrm{NaCl}$ ) with $1 \mathrm{mM}$ DTT in the presence of protease inhibitors (Roche). Lysates were cleared by centrifugation at $10,000 \mathrm{~g}$ for $10 \mathrm{~min}$. Total protein concentration was determined, and $30 \mu \mathrm{g}$ protein was loaded onto $10 \%$ SDS-polyacrylamide gel electrophoresis gels and transferred to nitrocellulose (Bio-Rad). Membranes were blocked for $1 \mathrm{~h}$ in 5\% milk prepared in PBS with $0.1 \%$ Tween-20 and probed overnight at $4{ }^{\circ} \mathrm{C}$ with anti-HA (1:1,000 in 5\% milk, Covance clone 16B12, MMS-101) or anti-tubulin antibodies $(1: 10,000$ in $5 \%$ milk, Sigma clone DM1A, T9026). After washing, membranes were incubated with anti-mouse horseradish peroxidase-linked secondary antibody (1:10,000 in 5\% milk) for $1 \mathrm{~h}$. Proteins were visualized with Western Lightning Plus-ECL Enhanced Chemiluminescence (Perkin Elmer). Uncropped images of Western blots are shown in Supplementary Fig. 5.

Statistical analysis. All data analyses were performed using GraphPad software. Numerical data are shown as the mean \pm s.d. Significant differences between sample groups were determined using a Student's $t$-test. $P$ values of $<0.05$ are considered statistically significant and are indicated with asterisks as follows: ${ }^{\star} P \leq 0.01,{ }^{*} P \leq 0.001$ and ${ }^{* * *} P \leq 0.0001$.

Data availability. All relevant data are available from the authors on request. Raw data for all graphs and tables are provided in Supplementary Data 1.

\section{References}

1. Chapman, J. R., Taylor, M. R. \& Boulton, S. J. Playing the end game: DNA double-strand break repair pathway choice. Mol. Cell 47, 497-510 (2012).

2. Kass, E. M. \& Jasin, M. Collaboration and competition between DNA double-strand break repair pathways. FEBS Lett. 584, 3703-3708 (2010).

3. Pannunzio, N. R., Li, S., Watanabe, G. \& Lieber, M. R. Non-homologous end joining often uses microhomology: implications for alternative end joining. DNA Repair (Amst) 17, 74-80 (2014).

4. Essers, J. et al. Homologous and non-homologous recombination differentially affect DNA damage repair in mice. EMBO J. 19, 1703-1710 (2000).

5. Prakash, R., Zhang, Y., Feng, W. \& Jasin, M. Homologous recombination and human health: the roles of BRCA1, BRCA2, and associated proteins. Cold Spring Harb. Perspect. Biol. 7, a016600 (2015).

6. Walsh, T. \& King, M. C. Ten genes for inherited breast cancer. Cancer Cell 11, 103-105 (2007).

7. Visvader, J. E. \& Stingl, J. Mammary stem cells and the differentiation hierarchy: current status and perspectives. Genes Dev. 28, 1143-1158 (2014).

8. Britt, K., Ashworth, A. \& Smalley, M. Pregnancy and the risk of breast cancer. Endocr. Relat. Cancer 14, 907-933 (2007).

9. Barcellos-Hoff, M. H. New biological insights on the link between radiation exposure and breast cancer risk. J. Mammary Gland Biol. Neoplasia 18, 3-13 (2013).

10. Moynahan, M. E., Akgun, E. \& Jasin, M. A model for testing recombinogenic sequences in the mouse germline. Hum. Mol. Genet. 5, 875-886 (1996).

11. Akgun, E. et al. Palindrome resolution and recombination in the mammalian germ line. Mol. Cell. Biol. 17, 5559-5570 (1997).

12. Hendricks, C. A. \& Engelward, B. P. 'Recombomice': the past, present, and future of recombination-detection in mice. DNA Repair (Amst) 3, 1255-1261 (2004).

13. Brown, A. D., Claybon, A. B. \& Bishop, A. J. A conditional mouse model for measuring the frequency of homologous recombination events in vivo in the absence of essential genes. Mol. Cell. Biol. 31, 3593-3602 (2011).

14. Wiktor-Brown, D. M., Sukup-Jackson, M. R., Fakhraldeen, S. A., Hendricks, C. A. \& Engelward, B. P. p53 null fluorescent yellow direct repeat (FYDR) mice have normal levels of homologous recombination. DNA Repair (Amst) 10, 1294-1299 (2011).

15. Kass, E. M. et al. Double-strand break repair by homologous recombination in primary mouse somatic cells requires BRCA1 but not the ATM kinase. Proc. Natl Acad. Sci. USA 110, 5564-5569 (2013).

16. Pierce, A. J., Johnson, R. D., Thompson, L. H. \& Jasin, M. XRCC3 promotes homology-directed repair of DNA damage in mammalian cells. Genes Dev. 13, 2633-2638 (1999).

17. Rouet, P., Smih, F. \& Jasin, M. Expression of a site-specific endonuclease stimulates homologous recombination in mammalian cells. Proc. Natl Acad. Sci. USA 91, 6064-6068 (1994).

18. Roy, R., Chun, J. \& Powell, S. N. BRCA1 and BRCA2: different roles in a common pathway of genome protection. Nat. Rev. Cancer 12, 68-78 (2012).

19. Sotillo, R. et al. Mad2 overexpression promotes aneuploidy and tumorigenesis in mice. Cancer Cell 11, 9-23 (2007).

20. Stark, J. M., Pierce, A. J., Oh, J., Pastink, A. \& Jasin, M. Genetic steps of mammalian homologous repair with distinct mutagenic consequences. Mol. Cell. Biol. 24, 9305-9316 (2004).

21. Watson, C. J. \& Khaled, W. T. Mammary development in the embryo and adult: a journey of morphogenesis and commitment. Development 135 , 995-1003 (2008).

22. Sleeman, K. E., Kendrick, H., Ashworth, A., Isacke, C. M. \& Smalley, M. J. CD24 staining of mouse mammary gland cells defines luminal epithelial, myoepithelial/basal and non-epithelial cells. Breast Cancer Res. 8, R7 (2006).

23. Stingl, J. et al. Purification and unique properties of mammary epithelial stem cells. Nature 439, 993-997 (2006).

24. Shackleton, M. et al. Generation of a functional mammary gland from a single stem cell. Nature 439, 84-88 (2006). 
25. Bai, L. \& Rohrschneider, L. R. s-SHIP promoter expression marks activated stem cells in developing mouse mammary tissue. Genes Dev. 24, 1882-1892 (2010).

26. Moynahan, M. E., Pierce, A. J. \& Jasin, M. BRCA2 is required for homology-directed repair of chromosomal breaks. Mol. Cell 7, 263-272 (2001).

27. McAllister, K. A. et al. Cancer susceptibility of mice with a homozygous deletion in the COOH-terminal domain of the Brca2 gene. Cancer Res. 62, 990-994 (2002).

28. van der Hout, A. H. et al. A DGGE system for comprehensive mutation screening of BRCA1 and BRCA2: application in a Dutch cancer clinic setting. Hum. Mutat. 27, 654-666 (2006).

29. Sukup-Jackson, M. R. et al. Rosa26-GFP direct repeat (RaDR-GFP) mice reveal tissue- and age-dependence of homologous recombination in mammals in vivo. PLoS Genet. 10, e1004299 (2014).

30. Wesoly, J. et al. Differential contributions of mammalian Rad54 paralogs to recombination, DNA damage repair, and meiosis. Mol. Cell. Biol. 26, 976-989 (2006).

31. Blanpain, C., Mohrin, M., Sotiropoulou, P. A. \& Passegue, E. DNA-damage response in tissue-specific and cancer stem cells. Cell Stem Cell 8, 16-29 (2011).

32. Giraddi, R. R. et al. Stem and progenitor cell division kinetics during postnatal mouse mammary gland development. Nat. Commun. 6, 8487 (2015).

33. Perou, C. M. et al. Molecular portraits of human breast tumours. Nature 406, 747-752 (2000).

34. Chang, T. H. et al. New insights into lineage restriction of mammary gland epithelium using parity-identified mammary epithelial cells. Breast Cancer Res. 16, R1 (2014).

35. Matulka, L. A., Triplett, A. A. \& Wagner, K. U. Parity-induced mammary epithelial cells are multipotent and express cell surface markers associated with stem cells. Dev. Biol. 303, 29-44 (2007).

36. Wagner, K. U. et al. An adjunct mammary epithelial cell population in parous females: its role in functional adaptation and tissue renewal. Development 129, 1377-1386 (2002)

37. Caldon, C. E. Estrogen signaling and the DNA damage response in hormone dependent breast cancers. Front. Oncol. 4, 106 (2014).

38. Williamson, L. M. \& Lees-Miller, S. P. Estrogen receptor alpha-mediated transcription induces cell cycle-dependent DNA double-strand breaks. Carcinogenesis 32, 279-285 (2011)

39. Meyer, S. et al. Fanconi anaemia, BRCA2 mutations and childhood cancer: a developmental perspective from clinical and epidemiological observations with implications for genetic counselling. J. Med. Genet. 51, 71-75 (2014).

40. Hay, T., Patrick, T., Winton, D., Sansom, O. J. \& Clarke, A. R. Brca2 deficiency in the murine small intestine sensitizes to p53-dependent apoptosis and leads to the spontaneous deletion of stem cells. Oncogene 24, 3842-3846 (2005).

41. Inman, J. L., Robertson, C., Mott, J. D. \& Bissell, M. J. Mammary gland development: cell fate specification, stem cells and the microenvironment. Development 142, 1028-1042 (2015).

42. Visvader, J. E. Cells of origin in cancer. Nature 469, 314-322 (2011).

43. Lim, E. et al. Aberrant luminal progenitors as the candidate target population for basal tumor development in BRCA1 mutation carriers. Nat. Med. 15, 907-913 (2009).
44. Molyneux, G. et al. BRCA1 basal-like breast cancers originate from luminal epithelial progenitors and not from basal stem cells. Cell Stem Cell 7, 403-417 (2010).

45. Lemaitre, C. et al. The nucleoporin 153, a novel factor in double-strand break repair and DNA damage response. Oncogene 31, 4803-4809 (2012).

\section{Acknowledgements}

We thank Chun-Chin Chen and other members of the Jasin lab for helpful discussions. We are grateful for the expert technical support from the following members of the core facilities at MSKCC: Dr Peter Romanienko (Mouse Genetics); Christi O’Donnel and Diane Domingo (Flow Cytometry); Dr Katia Manova-Todorova, Ning Fan, Afsar Barlas, Dmitry Yarilin, Sho Fujisawa and Navid Paknejad (Molecular Cytology); and Dr Gouri Nanjangud, Christine Rice and Kalyani Chadalavada (Molecular Cytogenetics). We thank Evi Soutoglou for generously providing the pWHE-320-HA-I-SceI plasmid. This work was supported by grants to E.M.K. from the Terri Brodeur Breast Cancer Foundation, MSKCC Clinical Scholars Biomedical Research Fellowship, and NIH K99 CA184122, and grants P01 CA094060 (M.E.M. and M.J.), Stand Up To Cancer-Ovarian Cancer Research Fund-Ovarian Cancer National Alliance-National Ovarian Cancer Coalition Dream Team Translational Research Grant (grant number: SU2C-AACR-DT16-15), MSK Cancer Center Support Grant/Core Grant P30 CA008748 and R01 CA185660 (M.J.).

\section{Author contributions}

E.M.K., M.E.M. and M.J. conceived the project, designed the experiments and wrote the manuscript. E.M.K., P.X.L. and H.R.H. performed the research.

\section{Additional information}

Supplementary Information accompanies this paper at http://www.nature.com/ naturecommunications

Competing financial interests: The authors declare no competing financial interests.

Reprints and permission information is available online at http://npg.nature.com/ reprintsandpermissions/

How to cite this article: Kass, E. M. et al. Robust homology-directed repair within mouse mammary tissue is not specifically affected by Brca2 mutation. Nat. Commun. 7, 13241 doi: 10.1038/ncomms13241 (2016).

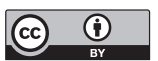

This work is licensed under a Creative Commons Attribution 4.0 International License. The images or other third party material in this article are included in the article's Creative Commons license, unless indicated otherwise in the credit line; if the material is not included under the Creative Commons license, users will need to obtain permission from the license holder to reproduce the material. To view a copy of this license, visit http://creativecommons.org/licenses/by/4.0/

C The Author(s) 2016 